\title{
Under nutrition and Associated Factors Among Adult People Attending Highly Active Anti-Retroviral Therapy in Health Facilities of Bench Maji Zone, South West Ethiopia, 2018.
}

Tilahun Mekonnen Regassa ( $\nabla$ tilahunmekonnen69@yahoo.com )

Mizan-Tepi University

Tesfaye Abera Gudeta

Mizan-Tepi University

Research

Keywords: Under nutrition, associated factors, HAART, MTU, Ethiopia

Posted Date: September 1st, 2020

DOI: https://doi.org/10.21203/rs.3.rs-67733/v1

License: (c) (1) This work is licensed under a Creative Commons Attribution 4.0 International License.

Read Full License 


\section{Abstract}

Background - Malnutrition is a condition in which a nutrition deficiency, excess or imbalance of energy, protein, and other nutrients causes adverse effects on tissue/body form. Nutritional issues are common in HIV disease. At some point, almost everyone living with HIV will face challenges in maintaining good nutrition.

Objective - To assess under nutrition and associated factors among Adult Clients on Highly Active Antiretroviral Therapy in Health Facilities of Bench Maji Zone, South West Ethiopia,2018.

Methods - Institutional based cross sectional study design with quantitative data collection was employed from May 01 - June 30/2018. A total sample size was 1007 and the participants were selected by using consecutive sampling technique from selected health facilities. EpiData Statistical software version 3.1 and Statistical Package for Social Sciences (SPSS) software version 21.0 were used for data entry and analysis. Logistic regression analysis was used to identify factors associated to under nutrition in adults attending ART. Odds ratios with $95 \%$ confidence intervals were used to examine associations between dependent \& independent variables. P. value less than 0.05 was considered significant.

Result: The magnitude of under nutrition among peoples on ART in this study was 154 (16.0\%). In multivariable logistic regression analysis, factors contributing to under nutrition were identified; Age [AOR 2.4, 95\% Cl (1.1-5.4)], marital status[AOR 2.2, 95\% Cl (1.3-3.7)], occupational status[AOR 0.4,95\% (0.20.9)], developing $\mathrm{Gl}$ symptoms [AOR 2.6, 95\% $\mathrm{Cl}(1.5-4.5)$ ] and WHO clinical stage [AOR 3.1, 95\% $\mathrm{Cl}(1.4-$ 6.8)].were found to have statistically significant association with among peoples on ART.

Conclusion: Significant numbers of peoples on ART drugs in the study area were under nutrition .Age, marital status, occupational status, WHO clinical stage of disease and developing gastro intestinal symptoms were identified factors of under nutrition among adult people on ART. The health care workers and experts work on the ART clinic should focuses on patient counseling about early prevention, detection and treatment of opportunistic infection, early health seeking behaviors before AIDs stage.

\section{Introduction}

Malnutrition and HIV are highly related to each other, which mean that malnutrition contributes for HIV infection and more likely to progress faster to AIDS also HIV-infection increases the risk of malnutrition because of reduced food intake, poor absorption, metabolic changes, chronic infections and illnesses, anorexia, diarrhea, fever, nausea/frequent vomiting, thrush and anemia. Beside to this everybody living with HIV will face challenges in maintaining good nutrition at some point, because of HIV infection itself and the effects of highly active anti retro virus (HAART). The virus can infect some of the immune cells in the intestines, leading local inflammation and making it more difficult to absorb nutrients and medicines, so that it can result in weight loss or mineral and vitamin deficiencies. Therefore, all people with HIV/ 
AIDS have special nutritional needs. Once the individuals start HAART, still nutrition is an important plan to keep healthy and body's immune system strong [1, 2].

Globally about 36 million persons are living with HIV/AIDS, 25 million of them in Africa and the HIV/AIDS epidemic is occurring in populations where malnutrition is already endemic [2,3]. HIV/AIDS epidemic is increasingly driven by and contributes to create malnutrition. Integration of nutrition into the essential package of care, treatment and support for people living with HIV/AIDS and efforts to prevent infection is the urgent response to this situation [4].

In Ethiopia HIV is epidemic. In 2007, about 980,000 people were living with HIV/AIDS: of these 260,000 including 16,000 children were in demand of ART [5].The national prevalence of HIV infection in Ethiopia is $1.2 \%$ ( $1.6 \%$ for females and $0.8 \%$ for men) among adult population in 2014 . The prevalence of HIV infection in the same year is $3.3 \%$ (male $2.3 \%$, female $4.4 \%$ ) in urban and $0.5 \%$ (male $0.3 \%$, female $0.6 \%$ ) in rural area [6].

The prevalence of both HIV/AIDS and malnutrition is high in numerous parts of the world, including subSaharan Africa. Their consequences are interrelated and aggravate one another. Both malnutrition and HIV can individually cause advanced damage to the immune system and increased vulnerability to infection, morbidity and mortality through opportunistic infections, diarrhea, fever, loss of appetite, nutrient mal-absorption, and weight loss. HIV specifically affects nutritional status by increasing energy demands, decreasing food intake, and impairs nutrient absorption and metabolism [7]. Studies have showed that people living with HIV who have a healthy diet can well tolerate HIV drugs, maintain a healthy weight, and feel better overall [8].

A nutritional assessment done in Ethiopia showed that $15 \%$ of clients on ART had a BMI less than 18.5 [5].But, the current magnitude of malnutrition status among adults on HAART in the study areas is not known. The results of the study provide valuable information for the design of possible programs and interventions that health professionals will use to improve the quality of life of people living with HIV/AIDS. Thus this study was aimed to assess under nutrition and associated factors among ART attending adult clients in Bench Maji Zone health facilities.

\section{Methods And Materials}

\section{Study area and period}

This study was conducted from May 01 - June 30/2018 in Bench Maji Zone. Bench Maji Zone is one of the Zones of the Ethiopian Southern Nations, Nationalities and Peoples Region (SNNPR) and found $565 \mathrm{~km}$ away from the capital city. Bench Maji is bordered on the south by the llemi Triangle, on the west by South Sudan, on the northwest by the Gambela Region, on the north by Sheka, on the northeast by Keffa, and on the east by Debub Omo. The Omo River defines much of its eastern border with Debub Omo. The administrative center of Bench Maji Zone is Mizan Aman. This zone consists of one city administration, 10 woredas. Currently there are 2499 people are on HAART in the Bench Maji Zone in 12 
health Facilities where this service is being given. In the Bench Maji Zone there is one teaching Hospital and 39 Health centers.

\section{Study design}

Institutional based cross sectional study design with quantitative methods of data collection was employed to assess malnutrition and associated factors among adults attending HAART clinic.

\section{Source population}

The sampled adult clients taking HAART in the selected health facilities from all adults receiving HAART in facilities of Bench Maji zone were the study subjects included in the study.

\section{Inclusion and exclusion criteria}

All adults 18 years and above and started HAART in selected Health facilities were included in the study. Patients who have kyphoscoliosis (for height measurement), critically ill and unable to communicate, HIV cases, not yet started ART, and pregnant woman were excluded from the study.

\section{Sample size determination and sampling technique}

The sample size was calculated using a single population proportion sample size calculation formula using the assumptions of margin of error of $3 \%$ with $95 \%$ confidence intervals, $a=0.05$ (level of significance), $\mathrm{P}=31.2 \%$ (9) assumed the proportion under nutrition among peoples on ART. After adding 10\% non-response rate, the final sample size was 1007.

From the health facilities that are giving the ART service, five health facilities were selected by SRS technique of lottery method. Based on the source of population, the sample size was proportionally allocated to each HF. The study subjects were interviewed consecutively until the sample size was achieved.

\section{Study Variables}

\section{Dependent variables}

Under nutrition in adults on HAART

\section{Independent variables}

- Socio-demographic characteristics: Age, Sex, Marital status, Occupation, Educational status, residence, Family size.

- Medical factors :Clinical stage, CD4 count, Opportunistic infection, Duration of ART, Current regimen of ART ,Side effect of ART, Drug adherence

- Nutritional related factors :Meal frequency ,Food diversity, Nutritional support ,Food support ,Dietary counseling 
- Life style:Consumed Alcohol, Smoking Cigarette, Chewing chat, Living condition, Source of drinking water, Physical exercise

\section{Operational definition and definition of terms}

Under nutrition-in this study operationalized if the BMI is less than 18.5 , after calculating by using the formula: $\mathrm{BMI}=$ Weight in kgs/ (Height in $\mathrm{mts})^{2}[7]$. Measurement on body weight was conducted using a standard beam balance that is used in the medical setup recorded to the nearest $0.1 \mathrm{~kg}$. The body weight was taken with subject light clothed and shoes taken off. Besides, over worn closes such as scarf in case of women was also asked to remove during body weight measurements. Similarly height measurements was carried out while the subject removed his/her shoes, stand erect, looking straight in a horizontal plane with feet together and knees straight. During this measurement the heels, buttocks, shoulder blades and the back of the head was adjusted to touch against the wall and the measurements was recorded to the nearest $0.5 \mathrm{~cm}[10]$.

\section{Dietary diversity}

was computed and dichotomized into two categories; from the 9 food items score if less than 4 score it was taken as low dietary diversity score and high dietary diversity score if greater than 5 score.

\section{Good adherence}

there is good adherence if the average adherence is greater than $95 \%$ (he/she missed $\leq 2$ doses of 30 doses or $\leq 3$ doses of 60 doses).

\section{Fair adherence}

there is fair adherence if the average adherence is $85-94 \%$ (he/she missed $3-5$ doses of 30 doses or $3-9$ doses of 60 doses).

\section{Poor adherence}

there is poor adherence if the average adherence is $<85 \%$ (he/she missed $\geq 6$ doses from 30 doses or $>9$ doses of 60 doses) [11].

\section{Data collection technique and tools}

The data was collected using pre-tested structured questionnaire. The structured questionnaire adapted reviewing different literatures [10-15].Dietary diversity was calculated using questionnaire adopted from FAO guidelines [16]. A food frequency and diversity questionnaire was used to obtain information about usual food consumption pattern of the client and a total dietary diversity score was calculated from a 24 hrs recalled list of food items consumed over the previous day. Food frequency is score the individual eat less than three per day is poor food frequency. All medical factors were assessed according to ART follow 
up on registration book. The face to face validity was checked by experts. The questions and statements were grouped and arranged according to the particular objectives that they can address.

\section{Data collectors and Data Collection Procedure}

Eight data collectors who are clinical nurses those work in ART clinic were recruited purposively and two supervisors who have Msc in health were recruited. Data was collected through face to face interview using pre -tested structured questionnaire and patient ART registration book.

\section{Quality control measures}

The quality of the data was assured by using pre-tested questionnaires. Prior to the actual data collection, pre-testing was done on $5 \%$ of the total study eligible subjects and have similar characteristics on nonselected health facility which was not be included in the analysis of the actual study and based on findings necessary amendments were made. Data collectors were trained for two days intensively on the study instrument and data collection procedure that includes the relevance of the study, objective of the study, confidentiality of the information, informed consent and interview technique. The data collectors worked under close supervision of the supervisors to ensure adherence to correct data collection procedures. Supervisors (investigators) reviewed the filled questionnaires in between data collection for completeness. Moreover, the data were carefully entered and cleaned before the beginning of the analysis.

\section{Data processing and analysis}

EPI data Statistical software version 3.1 and Statistical Package for Social Sciences (SPSS) software version 21.0 were used for data entry and analysis. After organizing and cleaning the data, frequencies \& percentages were calculated to all variables that are related to the objectives of the study. Variables with P- value of less than 0.25 in binary logistic regression analysis were entered into the multivariable logistic regression analysis to control confounds so that the separate effects of the various factors associated with under nutrition were assessed. Odds ratios with $95 \%$ confidence intervals were used to examine associations between dependent \& independent variables. P. value less than 0.05 was considered significant. Finally the result was presented using tables, charts and narrative form.

\section{Ethical considerations}

Ethical clearance from Mizan Tepi University, Institutional research committee (Dr.Henok kassa, Dr.desaleng ,Mr.muktar sano,Mrs.Nardos Delelegne,Mr.melak Menberu) and permission letter from respective authorities and verbal consent of respondents' was obtained before the data collection. To get full co-operation, respondents were reassured about the confidentiality of their response. They were also be ensured their voluntarily participation and right to take part or terminate at any time they wanted. Since the subject of the study could raise ethical issues care were taken in the design of the questionnaire. The research assistants were trained by the principal investigators on how to keep the confidentiality and anonymity of the responses of the respondents in all aspect. 


\section{Communication of the findings}

Final report of the study was given to the relevant offices as soon as the report was submitted to the Research office of Mizan-Tepi University. In addition to this, a copy of the final report of this study will be published and the journal will be disseminated to different national and international agencies.

\section{Result}

\section{Socio- demographic characteristics of the study participants}

Out of the total 1007 participants, 961 participants were participated in the study that gives $95.4 \%$ of response rate. More than half $588(61.2 \%)$ of the study participants were female and $412(42.9 \%)$ were found between 30-39 age group. Around half 550 (57.2\%) participants were married and majority $681(70.9 \%)$ of the study participants were urban by their residence. More than half 555(57.8\%) of participants were orthodox followed by protestants, and $411(42.8 \%)$ of the study participants had primary cycle regarding their educational status. Most of the study participants $905(94.2 \%)$ had less than or equal to five family size and around half 503(52.3\%) of them live with their spouse and children. Five hundred seventy eight $(60.1 \%)$ were used tap water as source of water for drinking and half of study participants were got less than 1000ETB average family monthly income (Table 1). 
Table 1

Socio-demographic characteristics of the study participants at Bench Maji Zone, southwest, Ethiopia, 2018.

\begin{tabular}{|c|c|c|c|}
\hline Variable & category & Frequency $(n=961)$ & Percent (\%) \\
\hline \multirow[t]{4}{*}{ Age } & $18-29$ & 320 & 33.3 \\
\hline & $30-39$ & 412 & 42.9 \\
\hline & $40-49$ & 179 & 18.6 \\
\hline & $>=50$ & 50 & 5.2 \\
\hline \multirow[t]{2}{*}{ Sex } & Male & 372 & 38.8 \\
\hline & Female & 588 & 61.2 \\
\hline \multirow[t]{4}{*}{ Marital status } & Single & 181 & 18.8 \\
\hline & Married & 550 & 57.2 \\
\hline & Widowed & 97 & 10.1 \\
\hline & Divorced & 133 & 13.8 \\
\hline \multirow[t]{2}{*}{ Residence } & Urban & 681 & 70.9 \\
\hline & Rural & 280 & 29.1 \\
\hline \multirow[t]{4}{*}{ Religion } & Orthodox & 555 & 57.8 \\
\hline & Muslim & 192 & 20.0 \\
\hline & Protestant & 210 & 21.9 \\
\hline & other & 3 & 0.3 \\
\hline \multirow[t]{5}{*}{ Educational status } & Illiterate & 221 & 23.0 \\
\hline & Can read and write & 60 & 6.2 \\
\hline & Primary Cycle(1-8) & 411 & 42.8 \\
\hline & Secondary school (9-12) & 206 & 21.4 \\
\hline & Diploma and above & 63 & 6.6 \\
\hline \multirow[t]{4}{*}{ Occupation } & Housewife & 227 & 23.6 \\
\hline & Farmer & 145 & 15.1 \\
\hline & Governmental employee & 110 & 11.4 \\
\hline & Non-govt. employee & 36 & 3.7 \\
\hline
\end{tabular}




\begin{tabular}{|c|c|c|c|}
\hline Variable & category & Frequency $(n=961)$ & Percent (\%) \\
\hline & Merchant & 215 & 22.4 \\
\hline & Laborer & 157 & 16.3 \\
\hline & Others* & 71 & 7.4 \\
\hline \multirow[t]{2}{*}{ Family size category } & $<=5$ & 905 & 94.2 \\
\hline & $>5$ & 56 & 5.8 \\
\hline \multirow[t]{5}{*}{ Live with } & Parent & 173 & 18.0 \\
\hline & Relatives & 57 & 5.9 \\
\hline & Spouse & 48 & 5.0 \\
\hline & Spouse and Children & 503 & 52.3 \\
\hline & Alone & 180 & 18.7 \\
\hline \multirow[t]{4}{*}{ Source of drinking water } & Tap & 578 & 60.1 \\
\hline & Spring & 251 & 26.1 \\
\hline & River & 51 & 5.3 \\
\hline & Well & 81 & 8.4 \\
\hline \multirow[t]{3}{*}{ Family monthly income } & $<1000$ & 487 & 50.7 \\
\hline & $1001-2000$ & 346 & 36.0 \\
\hline & $>2000$ & 128 & 13.3 \\
\hline
\end{tabular}

\section{Prevalence of under nutrition}

The magnitude of under nutrition among peoples on ART in this study was $154(16.0 \%(95 \% \mathrm{Cl}=13.8-$ 18.3)

\section{Life style of participants}

From the total study participants, most of them 887 (92.3\%) did not smoke cigarette and only 206 (21.4\%) participants drunk alcohol. Few study participants $106(11.0 \%)$ chewed chat and majority 692 (72.0) participants were performing regular physical exercise.

\section{Medical and health status of the participants}

From the participants majority of them $870(90.5 \%)$ were on stage I of WHO clinical stage of disease in the last 6 months. The recent CD4 number of the participants ranged between $23-2000 \mathrm{cell} / \mathrm{mm}^{3}$ with mean $610 \pm 273.6$ and the CD 4 number of most of the participants $651(67.7 \%)$ was greater than 500 
cell/ $\mathrm{mm}^{3}$. Only $100(10.4)$ of the study subjects developed opportunistic infection previously, of which $329(32 \%)$ accounted Tuberculosis and 107(11.1) developed other gastrointestinal symptoms from which poor appetite/ anorexia accounted 47(43.1) and PUD of Dyspepsia 47(43.1) followed by difficulty of eating 35(35\%).Most of the participants 633(65.95) spend more than 5 years since diagnosed HIV infected. The most used ART regimen 597(62.1\%) was TDF + 3TC + EFV followed by AZT + 3TC + NVP $200(20.8 \%)$ and majority of them $693(72.1 \%)$ spend greater than 3 years since started ART drugs. Only $47(4.9 \%)$ developed Side effect of HAART and most of them were $899(93.5 \%)$ on good drug adherence (Table 2). 
Table 2

Variable related to medical factor of the study participants at Bench Maji Zone, southwest, Ethiopia, 2018.

\begin{tabular}{|c|c|c|c|}
\hline Variable & category & $\begin{array}{l}\text { Frequency }(\mathrm{n} \\
=961)\end{array}$ & $\begin{array}{l}\text { Percent } \\
(\%)\end{array}$ \\
\hline \multirow[t]{4}{*}{ WHO Clinical stage of the disease } & Stage-I & 870 & 90.5 \\
\hline & Stage-II & 34 & 3.5 \\
\hline & Stage-III & 51 & 5.3 \\
\hline & Stage-IV & 6 & 0.6 \\
\hline \multirow[t]{3}{*}{ Recent CD 4 count of the patient } & $<200$ & 64 & 6.7 \\
\hline & $200-499$ & 246 & 25.6 \\
\hline & $>500$ & 651 & 67.7 \\
\hline \multirow[t]{2}{*}{ Previous Opportunistic infection } & Yes & 100 & 10.4 \\
\hline & No & 861 & 89.6 \\
\hline \multirow{5}{*}{$\begin{array}{l}\text { Type of previous opportunistic infection the patient } \\
\text { developed }(n=100)\end{array}$} & Oral Candidiasis & 18 & 18.0 \\
\hline & Tuberculosis & 32 & 32.0 \\
\hline & Chronic Diarrhea & 21 & 21.0 \\
\hline & Anemia & 13 & 13.0 \\
\hline & Other^ & 16 & 16.0 \\
\hline \multirow[t]{2}{*}{ Other gastrointestinal symptoms developed } & Yes & 107 & 11.1 \\
\hline & No & 854 & 88.9 \\
\hline \multirow[t]{4}{*}{ Type gastrointestinal symptoms developed $(n=109)$} & $\begin{array}{l}\text { Poor appetite/ } \\
\text { Anorexia }\end{array}$ & 47 & 43.1 \\
\hline & $\begin{array}{l}\text { Difficulty of } \\
\text { eating }\end{array}$ & 39 & 35.8 \\
\hline & $\begin{array}{l}\text { Nausea and } \\
\text { vomiting }\end{array}$ & 23 & 21.1 \\
\hline & $\begin{array}{l}\text { PUD or } \\
\text { Dyspepsia }\end{array}$ & 47 & 43.1 \\
\hline \multirow[t]{2}{*}{ Time since HIV Diagnosis in months } & $<12$ months & 82 & 8.5 \\
\hline & $12-36$ months & 134 & 13.9 \\
\hline \multicolumn{4}{|c|}{ Other*- $T D F+3 T C+A T V / r, A B C+3 T C+L P V / r, A B C+3 T C+A T V / r$} \\
\hline \multicolumn{4}{|l|}{ Other^-pneumonia, epilepsy, herpes zoster } \\
\hline
\end{tabular}




\begin{tabular}{|c|c|c|c|}
\hline Variable & category & $\begin{array}{l}\text { Frequency (n } \\
=961)\end{array}$ & $\begin{array}{l}\text { Percent } \\
\text { (\%) }\end{array}$ \\
\hline & $36-60$ months & 112 & 11.7 \\
\hline & $>60$ months & 633 & 65.9 \\
\hline \multirow[t]{10}{*}{ Current ART regimen } & $\begin{array}{l}\text { 1c }(A Z T+3 T C+ \\
\text { NVP) }\end{array}$ & 200 & 20.8 \\
\hline & $\begin{array}{l}1 \mathrm{~d}(\mathrm{AZT}+3 \mathrm{TC}+ \\
\mathrm{EFV})\end{array}$ & 90 & 9.4 \\
\hline & $\begin{array}{l}\text { 1e (TDF + TC + } \\
\text { EFV) }\end{array}$ & 597 & 62.1 \\
\hline & $\begin{array}{l}1 f(T D F+3 T C+ \\
N V P)\end{array}$ & 47 & 4.9 \\
\hline & $\begin{array}{l}1 \mathrm{~g}(\mathrm{ABC}+3 \mathrm{TC} \\
+\mathrm{EFV})\end{array}$ & 4 & 0.4 \\
\hline & $\begin{array}{l}2 b(T D F+3 T C+ \\
\mathrm{LPV} / \mathrm{r})\end{array}$ & 3 & 0.3 \\
\hline & $\begin{array}{l}\text { 2c (TDF + } 3 T C+ \\
\mathrm{LPV} / \mathrm{r})\end{array}$ & 2 & 0.2 \\
\hline & $\begin{array}{l}\text { 2e (AZT-3TC- } \\
\text { LPV/r) }\end{array}$ & 1 & 0.1 \\
\hline & $\begin{array}{l}2 f(A Z T-3 T C- \\
\text { ATV/r) }\end{array}$ & 5 & 0.5 \\
\hline & Other* & 12 & 1.2 \\
\hline \multirow[t]{4}{*}{ Duration of ART in month } & $<6$ months & 49 & 5.1 \\
\hline & $6-12$ months & 67 & 7.0 \\
\hline & 12-36months & 152 & 15.8 \\
\hline & $>36$ months & 693 & 72.1 \\
\hline \multirow[t]{2}{*}{ Side effect of HAART } & Yes & 47 & 4.9 \\
\hline & No & 914 & 95.1 \\
\hline \multirow[t]{2}{*}{ Doses of ART drug } & 30 doses & 404 & 42.0 \\
\hline & 60 doses & 275 & 28.6 \\
\hline
\end{tabular}

Other*- $T D F+3 T C+A T V / r, A B C+3 T C+L P V / r, A B C+3 T C+A T V / r$.

Other^-pneumonia, epilepsy, herpes zoster 


\begin{tabular}{|c|c|c|c|}
\hline Variable & category & $\begin{array}{l}\text { Frequency (n } \\
=961)\end{array}$ & $\begin{array}{l}\text { Percent } \\
\text { (\%) }\end{array}$ \\
\hline & $\begin{array}{l}90 \text { and } 180 \\
\text { doses }\end{array}$ & 282 & 29.3 \\
\hline \multirow[t]{3}{*}{ Adherence status } & Poor & 44 & 4.6 \\
\hline & Fair & 18 & 1.9 \\
\hline & Good & 899 & 93.5 \\
\hline \multicolumn{4}{|c|}{ Other*- $T D F+3 T C+A T V / r, A B C+3 T C+L P V / r, A B C+3 T C+A T V / r$} \\
\hline \multicolumn{4}{|c|}{ Other^-pneumonia, epilepsy, herpes zoster } \\
\hline
\end{tabular}

\section{Nutritional related factors}

Among the participants only $64(6.7 \%)$ got food aids of which $495.1(5.1 \%)$ aids got this aid from government. Among the types of this food aids 43(68.3\%) was plump nut. High number of the participants $610(63.5 \%)$ got dietary counselling and most of them $884(92.0 \%)$ of them had good food frequency (diet more than three times per day).

\section{Diversified Diet}

A total dietary diversity score was calculated from a $24 \mathrm{hrs}$ recalled list of food items consumed over the previous day. According to the dietary diversity score about half $489(50.9 \%)$ got diversified diet

\section{Factors Affecting under nutrition among peoples on HAART}

In multivariable logistic regression analysis, factors contributing to under nutrition were identified. Adult people on HAART age greater and equal to 50 years old were two times more likely develop under nutrition as compared to younger age [AOR 2.4, 95\% $\mathrm{Cl}(1.1-5.4)$ ]. Being a single in marital status was two times more likely develop under nutrition in adult people receiving ART as compared to their counterpart [AOR 2.2, 95\% Cl (1.3-3.7)]. Being merchants among adult people on ART were less likely develop under nutrition by $60 \%$ as compared to employed individuals in government and non-government organization [AOR $0.4,95 \%(0.2-0.9)$ ] and those who manifested other $\mathrm{GI}$ symptoms were three times more likely faced under nutrition as compared to who didn't manifest[ AOR 2.6, 95\% $\mathrm{Cl}(1.5-4.5)]$. Adult client who were on WHO clinical stage III were three times more likely to be under nutrition as compared to their counterpart [AOR 3.1, 95\% $\mathrm{Cl}(1.4-6.8)]$ (Table 3). 
Table 3

Multivariable logistic regression analysis of under nutrition among peoples on HAART in Health facilities of Bench Maji Zone, Southwestern Ethiopia, 2018.

\begin{tabular}{|c|c|c|c|c|c|}
\hline \multirow[t]{2}{*}{ Variable } & \multirow[t]{2}{*}{ Category } & \multicolumn{2}{|c|}{$\begin{array}{l}\text { Under } \\
\text { nutrition }\end{array}$} & \multirow[t]{2}{*}{$\begin{array}{l}\text { COR }(95 \% \\
\mathrm{Cl})\end{array}$} & \multirow[t]{2}{*}{$\operatorname{AOR}(95 \% \mathrm{Cl})$} \\
\hline & & No & Yes & & \\
\hline \multirow[t]{4}{*}{ Age } & $18-29$ & 267 & 53 & 1 & 1 \\
\hline & $30-39$ & 354 & 58 & $0.8(0.6-1.2)$ & $1.1(0.7-1.9)$ \\
\hline & $40-49$ & 149 & 30 & $1.0(0.6-1.7)$ & $1.4(0.8-2.5)$ \\
\hline & $>=50$ & 37 & 13 & $1.8(0.9-3.6)$ & $\begin{array}{l}2.4(1.1- \\
5.4)^{\star}\end{array}$ \\
\hline \multirow[t]{4}{*}{ Marital status } & Married & 480 & 70 & 1 & 1 \\
\hline & Single & 136 & 45 & $2.3(1.5-3.5)$ & $\begin{array}{l}2.2(1.3- \\
3.7)^{\star}\end{array}$ \\
\hline & Widowed & 78 & 19 & $1.7(1.0-2.9)$ & $1.1(0.6-2.1)$ \\
\hline & Divorced & 113 & 20 & $1.2(0.7-2.1)$ & $0.9(0.5-1.7)$ \\
\hline \multirow[t]{2}{*}{ Residence } & Urban & 578 & 103 & 1 & 1 \\
\hline & Rural & 229 & 51 & $1.3(0.9-1.8)$ & $1.2(0.8-2.0)$ \\
\hline \multirow[t]{4}{*}{ Educational status } & Illiterate & 223 & 58 & $1.8(0.8-4.0)$ & $2.6(0.9-7.1)$ \\
\hline & Primary $(1-8)$ & 349 & 62 & $1.2(0.6-2.7)$ & $2.0(0.7-5.2)$ \\
\hline & $\begin{array}{l}\text { Secondary school(9- } \\
12)\end{array}$ & 180 & 26 & $1.0(0.4-2.3)$ & $1.4(0.5-3.6)$ \\
\hline & Diploma and above & 55 & 8 & 1 & 1 \\
\hline \multirow[t]{5}{*}{ Occupational status } & Employee(Gov't \&NGO) & 119 & 27 & 1 & 1 \\
\hline & Farmer \& house wife & 307 & 65 & $0.9(0.6-1.5)$ & $0.6(0.3-1.1)$ \\
\hline & Merchant & 191 & 24 & $0.6(0.3-1.0)$ & $\begin{array}{l}0.4(0.2- \\
0.9)^{\star}\end{array}$ \\
\hline & Laborer & 131 & 26 & $0.9(0.5-1.6)$ & $0.5(0.2-1.1)$ \\
\hline & Other & 59 & 12 & $0.9(0.4-1.9)$ & $0.6(0.2-1.4)$ \\
\hline \multirow{3}{*}{$\begin{array}{l}\text { Source of drinking } \\
\text { water }\end{array}$} & Tape water & 487 & 91 & 1 & 1 \\
\hline & Spring water & 213 & 38 & $1.0(0.6-1.4)$ & $0.9(0.6-1.5)$ \\
\hline & Liver water & 38 & 13 & $1.8(0.9-3.6)$ & $1.7(0.8-3.7)$ \\
\hline
\end{tabular}




\begin{tabular}{|c|c|c|c|c|c|}
\hline & Well water & 69 & 12 & $0.1(0.5-1.8)$ & $0.9(0.4-1.9)$ \\
\hline \multirow[t]{3}{*}{ CD4 count } & $<200$ & 45 & 19 & $2.3(1.3-4.0)$ & $1.5(0.8-3.0)$ \\
\hline & $200-499$ & 213 & 33 & $0.8(0.5-1.3)$ & $0.7(0.5-1.1)$ \\
\hline & $>=500$ & 549 & 102 & 1 & \\
\hline \multirow[t]{2}{*}{ Ol } & Yes & 69 & 31 & $2.7(1.7-4.3)$ & $0.9(0.5-1.8)$ \\
\hline & No & 738 & 123 & 1 & 1 \\
\hline \multirow[t]{2}{*}{ GI symptom } & Yes & 67 & 40 & $3.9(2.5-6.0)$ & $\begin{array}{l}2.6(1.5- \\
4.5)^{\star}\end{array}$ \\
\hline & No & 740 & 114 & 1 & 1 \\
\hline \multirow[t]{4}{*}{ WHO clinical stage } & Stage one & 745 & 125 & 1 & 1 \\
\hline & Stage two & 27 & 7 & $1.5(0.7-3.6)$ & $1.5(0.6-3.7)$ \\
\hline & Stage three & 32 & 19 & $3.5(1.9-6.4)$ & $\begin{array}{l}3.1(1.4- \\
6.8)^{\star}\end{array}$ \\
\hline & Stage four & 3 & 3 & $\begin{array}{l}6.0(1.2- \\
29.9)\end{array}$ & $\begin{array}{l}3.0(0.4- \\
20.6)\end{array}$ \\
\hline \multirow{5}{*}{$\begin{array}{l}\text { Time since HIV } \\
\text { diagnose }\end{array}$} & $<12$ months & 60 & 22 & $2.1(1.2-3.6)$ & $1.2(0.3-4.8)$ \\
\hline & 12-36 months & 112 & 22 & $1.1(0.7-1.9)$ & $0.8(0.3-2.0)$ \\
\hline & & & & 77 & \\
\hline & $36-60$ months & 96 & 16 & $1.0(0.5-1.7)$ & $0.7(0.3-1.4)$ \\
\hline & $>60$ months & 539 & 94 & 1 & 1 \\
\hline \multirow[t]{4}{*}{ Current ART regimen } & $1 \mathrm{c}(\mathrm{AZT}+3 \mathrm{TC}+\mathrm{NVP})$ & 164 & 36 & 1 & 1 \\
\hline & $1 \mathrm{~d}(\mathrm{AZT}+3 \mathrm{TC}+\mathrm{EFV})$ & 73 & 17 & $1.1(0.6-2.0)$ & $1.2(0.6-2.5)$ \\
\hline & $1 e(T D F+3 T C+E F V)$ & 504 & 93 & $0.8(0.6-1.3)$ & $0.7(0.4-1.1)$ \\
\hline & Other & 66 & 8 & $0.6(0.2-1.3)$ & $0.5(0.2-1.1)$ \\
\hline \multirow[t]{4}{*}{ Duration on ART } & $<6$ months & 35 & 14 & $2.3(1.2-4.5)$ & $1.5(0.3-6.7)$ \\
\hline & 6-12 months & 55 & 12 & $1.3(0.7-2.5)$ & $1.0(0.3-3.8)$ \\
\hline & $12-36$ months & 125 & 27 & $1.3(0.8-2.0)$ & $1.5(0.7-3.4)$ \\
\hline & $>36$ months & 592 & 101 & 1 & 1 \\
\hline Side effect of ART & Yes & 34 & 13 & $2.1(1.2-4.1)$ & $1.5(0.7-3.3)$ \\
\hline
\end{tabular}




\begin{tabular}{|llllll|}
\hline \multirow{2}{*}{ Drug adherence } & No & 773 & 141 & 1 & 1 \\
& Poor & 32 & 12 & $2.1(1.0-4.1)$ & $1.7(0.7-3.8)$ \\
\cline { 2 - 6 } & Fair & 14 & 4 & $1.6(0.5-4.9)$ & $1.4(0.4-4.7)$ \\
\cline { 2 - 6 } & Good & 761 & 138 & 1 & 1 \\
\hline Food frequency & Poor & 54 & 23 & $2.4(1.5-4.1)$ & $1.6(0.9-3.0)$ \\
\cline { 2 - 6 } & Good & 753 & 131 & 1 & \\
\hline Diet counseling & Yes & 505 & 105 & 1 & 1 \\
\cline { 2 - 6 } & No & 302 & 49 & $0.8(0.5-1.1)$ & $0.7(0.5-1.1)$ \\
\hline * Statistically significant & & & & & \\
\hline
\end{tabular}

\section{Discussion}

The magnitude of under nutrition in this study was $154(16.0 \%[95 \% \mathrm{Cl}=13.8-18.3])$. This implies that the significant number of peoples attending the ART clinicf developed under nutrition and HIV/AIDS has direct or indirect impact on nutritional status of the client those receiving HAART. The finding of this study was lower than the study done in Brazil[17] ,in Ethiopia: Bahir Dar [18], Dembia distric [12], Nekemte referral hospital[10], Wolaita Sodo [14], Butajira [11] and Hosana [9] which were 43\%, 25.5\%, 23.2\%,27\%, $26.6 \% 25.2 \%$ and $31.2 \%$ respectively. The discrepancy might be due to study period, increased health seeking behaviour of the community from time to time which enhance early detection and treatment of $\mathrm{HIV}$, and other reason is due to difference in socioeconomic status of the community which has direct relation with under nutrition and increased government intervention like early initiation of HAART and supplementation diet.

The finding of this study was higher than the study done in Zimbabwe [19] and Dilla university referral hospital (15) which was $10 \%$ and $12.3 \%$ respectively. The might be due to study area and the difference intervention given the study area on dietary practice.

In this study some associated factors were identified. Among socio demographic age, marital status and occupation were significantly associated with under nutrition in peoples on ART. This is consistent with the study done in Brazil [20].It is known that as age increases the immunity decreases that put the orders on different diseases and OI that affects the appetite and food intake of individuals. In this study being single in marital status is also associated with under nutrition in peoples on ART. This may indicate that unmarried individuals may at risk to develop HIV infection and if infected OI may follow that affects the food intake. The study done in Amhara region of Ethiopia, Dembia district indicated that widowed people were associated to under nutrition among people on ART [12]. In addition to this the finding of this study indicated that peoples those who merchants in occupation were less likely develop under nutrition. This might be due to the income of merchants is high than of employed to afford in getting the food. 
The other factor associated with under nutrition among adult peoples on ART in this study was developing gastro intestinal symptoms within last six months. This is consistent with the study conducted in Ethiopia, Bahir Dar, that indicated feeding difficulty was the predictor [18] and also similarly the study conducted at Dilla University Referral Hospital of the same country showed that gastrointestinal symptoms were associated factors of under nutrition among adult people taking ART drugs [15]. This might be due to that peoples with gastro intestinal symptoms cannot take food well and poor absorption of the food may also occur. In this study also WHO clinical stage of AIDS disease was significantly associated with being under nutrition in peoples on ART drugs. This finding is similar with the study done in Ethiopia at Nekemt referral hospital, Dilla University Referral Hospital, Hosanna town $[9,13,15]$.This is known that in Clinical stage four of AIDs diseases the patient develop many opportunistic infections that affects the appetite of the patients and even it is the stage at which the peoples become unable to feeding.

\section{Limitation of the study}

This research might be subjected to certain limitations like there might be inter observer error during measurements.

\section{Conclusion}

Significant numbers of peoples on ART drugs in the study area were under nutrition .Age, marital status, occupational status, WHO clinical stage of disease and developing gastro intestinal symptoms were identified factors of under nutrition among adult people on ART

\section{Abbreviations}

AIDS (Acquired Immunodeficiency Syndrome), ART (Antiretroviral Treatment),ARV (Antiretroviral),BMI( Body Mass Index),FMOH (Federal ministry of Health),HAART(Highly Active Antiretroviral Therapy), HAPCO ( HIV and AIDS Prevention and Control Office), HIV (Human Immuno-Deficiency Virus), MUAC(Measurement of upper Arm Circumferences),PPLHIV (People living with HIV/AIDS) ,RUTF (Ready to use therapeutic food)

\section{Declarations}

\section{Competing interests}

The authors declare that they have no competing interests.

\section{Availability of data and materials}

The data was stored and kept in personal computer of authors. 


\section{Ethics approval and consent to participate}

The ethical issue of the research was assured by obtaining ethical approval letters from the ethical committee of Mizan-Tepi University and permission letter from respective authorities and verbal consent of respondents' was obtained before the data collection. To get full co-operation, respondents were reassured about the confidentiality of their response. They were also be ensured their voluntarily participation and right to take part or terminate at any time they wanted. Since the subject of the study could raise ethical issues care were taken in the design of the questionnaire. The research assistants were trained by the principal investigators on how to keep the confidentiality and anonymity of the responses of the respondents in all aspect.

\section{Consent to publish}

Not applicable.

\section{Funding}

The study was funded by Mizan Tepi University.

\section{Authors' contributions}

The authors' responsibilities were as follows: Designed and supervised the study and ensured Quality of the data and assisted in the analysis and interpretation of the data. All authors critically reviewed the manuscript. The corresponding author did the analysis \& drafted the manuscript and had the responsibility to submit the manuscript for publication.

\section{Acknowledgements}

We are extremely grateful to the Mizan -Tepi University, study subjects involved in the study, and data collectors.

\section{References}

1. HIV/AIDS. A Guide for Nutrition, Care and Support. Food and Nutrition Technical Assistance Project, Academy for Educational Development, Washington DC, 2001.

2. Practical A Guide to Nutrition for People Living with HIV. Canadian AIDS Treatment Information Exchange, 2012.

3. World Health Organization. "Nutrient Requirements for people living with HIV/AIDS: Report of a Technical Consultation.” WHO: 2003, Geneva. 
4. WHO. Nutrition and HIV/AIDS Report by the Secretariat. Executive Board 116th Session Provisional Agenda item 4.3. 2005.

5. The Federal Democratic Republic of Ethiopia Ministry of Health. National Nutrition and HIV/AIDS Implementation Reference Manual,2008.

6. National Comprehensive HIV Care and Treatment Training for Health care Providers. Participant Manual, Ministry of Health, Ethiopia, 2014.

7. The United States. President's Emergency Plan for AIDS Relief Report on Food and Nutrition for People Living with HIV/AIDS, 2006.

8. The Well Project

Nutrition. and HIV. The Well Project,2016.

9. Hailu AsnakewM, Jarso C. H. Malnutrition and Associated Factors among Adult Individuals Receiving Highly Active Antiretroviral Therapy in Health Facilities of Hosanna Town, Southern Ethiopia. Open Access Library Journal. 2015;2:e1289.

10. Meskerem Ak, Sileshi G, Habtamu FG. Assessment of Adult Nutritional Status and Associated Factors among ART Users in Nekemte Referral Hospital and Health Center, East Wollega Zone, Ethiopia. Advances in Life Science and Technology. 2015; Vol.29.

11. Gedle, et al. Prevalence of malnutrition and its associated factors among adult people living with HIV/AIDS receiving anti-retroviral therapy at Butajira Hospital, southern Ethiopia. BMC Nutrition. 2015;1:5.

12. Anbesaw Mitiku TA, Ayele. Mekonen Assefa3 and Amare Tariku. Undernutrition and associated factors among adults living with Human Immune Deficiency Virus in Dembia District, northwest Ethiopia: an institution based cross-sectional study. Archives of Public Health. 2016;74:33.

13. Habtamu Mulu L, Hamza. Fesehaye Alemseged.Prevalence of Malnutrition and Associated Factors among Hospitalized Patients with Acquired Immunodeficiency Syndrome in Jimma University Specialized Hospital, Ethiopia. Ethiop J Health Sci. 2016;26:3.

14. Lula, Amza, Tsegaye Demissie,Yoseph Halala. Under nutrition and associated factors among adult on highly active antiretroviral therapy in Wolaita Sodo teaching and referral hospital, southern nation's nationalities people's region, Ethiopia. International Journal of Nutrition Metabolism. 2017;9(2):10-9.

15. Solomon Hailemariam GT, Bune, Henok Tadesse Ayele. Malnutrition: Prevalence and its associated factors in People living with HIV/AIDS, in Dilla University Referral Hospital. BMC, Archives of Public Health. 2013; 71:13.

16. FAO. Guidelines for measuring household and individual dietary diversity.2011.

17. Andrade CS, Jesus RP, Andrade TB, Oliveira NS, Nabity SA, et al. Prevalence and Characteristics Associated with Malnutrition at Hospitalization among Patients with Acquired Immunodeficiency Syndrome in Brazil. PLoS ONE. 2012;7:11.

18. Molla Daniel F, Mazengia D, Birhanu. Nutritional Status and Associated Factors Among Adult HIV/AIDS Clients in Felege Hiwot Referral Hospital, Bahir Dar, Ethiopia. Science Journal of Public 
Health. 2013;1(1):24-31. doi:10.11648/j.sjph.20130101.14.

19. Kudakwashe CT, Tsitsi MA, Bernard M, Brilliant N, Ancikaria C, Mirriam B, Monica M, Anthony DH, Owen M. Malnutrition status and associated factors among HIV-positive patients enrolled in ART clinics in Zimbabwe. BMC Nutrition. 2017;3:15. DOI 10.1186/s40795-017-0132-8.

20. Andrade CS, Jesus RP, Andrade TB, Oliveira NS, Nabity SA, et al. Prevalence and Characteristics Associated with Malnutrition at Hospitalization among Patients with Acquired Immunodeficiency Syndrome in Brazil. PLoS ONE. 2012;7:11.

21. Weldehaweria NB, Abreha EH, Weldu MG, Misgina KH. Psychosocial correlates of nutritional status among people living with HIV on antiretroviral therapy: A matched case-control study in Central zone of Tigray, Northern Ethiopia. PLoS ONE. 2017;12(3):e0174082.

22. Coates J, Swindale A, Bilinsky P. Household Food Insecurity Access Scale (HFIAS) for Measurement of Household Food Access: Indicator Guide Version 3. Washington DC: Food and Nutrition Technical Assistance Project Academy for Educational Development; 2007. 